\title{
BIRTH MEASUREMENTS PARTURITION DATES, AND PROGENY SEX RATIO OF DAMA DAMA IN DOÑNAN, SPAIN
}

\author{
Francisco Braza, Chistina San Jose, and Allakd Blom
}

Departamento de Etología, Estación Biológica Doñana, Apartado 1056, Sevilla, España

The theory of parental investment contains the prediction that parents will invest more in offspring of the sex that has a greater variance in reproductive success, and that individuals reeeiving a greater-thanaverage investment are more fit (Clutton-Brock et al., 1981; Maynard-Smith, 1980; Trivers, 1972, 1985; Trivers and Willard, 1973). In polygynous mammals, the male generally is the sex that has the largest varianee in reproductive success (Clutton-Brock and Alhon, 1979; Le Boeuf and Briggs, 1977). Moreover, reproductive success of males probably is related to early growth and parental investment. Thus, a larger investment by the parents in sons than in daughters wonld be expected. Indeed, male offspring of some mammals are heavier at birth than females (Clntton-Brock et al., 1982; Dittus, 1979; Reiter et al., 1978), have longer gestation lengths (Clntton-Brock et al., 1982), tend to be born carlier in the season (Clntton-Brock et al., 1982; Conlson and Hickling, 1961; Stirling, 1971), and grow faster (Robbins and Moen, 1975; Short, 1970). Our aim was to test for differences in parental investment between sexes at birth in fallow deer (Dama dama).

The study was conducted at the Biological Reserve of Donana, Donana National Park in SW Spain, from May 1982 to Jnly 1985; this period encompassed four fawning seasons. On the 7,500-ha Reserve, fallow deer inhabit an ecotone situated between maquis (Mediterranean shrubland) and marsh that dries during summer 
TARLE 1.-Average bith date for male and female fallow deer in Doñana, Spain. Mann-Whilney U test was used to compare birth dates between sexes.

\begin{tabular}{|c|c|c|c|c|c|c|c|c|c|}
\hline \multirow[b]{2}{*}{ Year } & \multicolumn{4}{|c|}{ Males } & \multicolumn{4}{|c|}{ Females } & \multirow{2}{*}{$\begin{array}{c}\text { Difference } \\
\text { belween sexes }\end{array}$} \\
\hline & $n$ & $\bar{x}$ & $S D$ & $C V$ & $n$ & $\overline{\mathbf{X}}$ & $S D$ & $C v$ & \\
\hline 1982 & 7 & 5 June & 2.2 & 19.6 & 5 & 5 June & 4.1 & 36.4 & n.s. \\
\hline 1983 & 10 & 30 May & 1.9 & 36.6 & 8 & 3 June & 4.3 & 477 & * \\
\hline 1984 & 5 & 31 May & 1.5 & 23.6 & 9 & 2 June & 4.7 & 60.3 & n.s. \\
\hline 1985 & 7 & 3 June & 1.8 & 20.2 & 6 & 3 June & 2.9 & 31.5 & n.s. \\
\hline Totals & 29 & 2 June & 2.9 & 38.0 & 28 & 3 June & 4.1 & 45.2 & \\
\hline
\end{tabular}

No signuficant difference $=11 \mathrm{~s}$

$* P<005$

(Braza, 1975). This ecotone consists mainly of different kinds of meadows and areas of rushes (Juncus). 'These areas are used mostly by fermales that seek the cover of the Juncus for parturition. Average annual rainfall in the area is about $500 \mathrm{~mm}$; the rainfall was $317 \mathrm{~mm}$ in $1981,561 \mathrm{~mm}$ in $1982,556 \mathrm{~mm}$ in 1983 , $461 \mathrm{~mm}$ in 1984, and $612 \mathrm{~mm}$ in 1985.

The population of female fallow deer (adnlt and young) on the study area was 95 individuals in 1982, 115 in 1983,118 in 1984, and 127 in 1985 . The small population in 1982 was related to high mortality resulting from the previous drought.

During the fawning season in the first 2 weeks of June, the marked females (approximately $10 \%$ of the population) were observed from dawn to dusk to determine the date of birth and to find their recently born fawns The unmarked females were counted daily and the age of their offspring, when the actual parturition had not been secn, was estimated by backdating aceording to the criteria of hoof hardening, degree of umbilical healing, and behavior based on offspring whose birth dates were known $(n=19)$; these eriteria seemed to provide a reliable estimale of age for fawns $\leq 3$ days old. Haugen and Speak (1958) nsed similar techniques for white-tailed deer (Odocoileus virginanus). We estimated that about $50 \%$ of the offspring born in the study area were captured.

Fawns were ear-tagged, weighed, and tbeir sex determined, and body length, length of hind foot, shoulder height, tail length, half of chest girth, and ear length were measured.

Analysis was restricted to 57 fawnis known $(n=19)$ or estimated $(n=38)$ to be $\leq 3$ days old. The average $( \pm S D)$ age of fawns at first capture was $1.58 \pm 0.66$ days in $1982 ; 1.55 \pm 0.70$ days in $1983 ; 171 \pm 0.82$ days in 1984; and $1.30 \pm 0.48$ days in 1985. Chi-square tests, Manm-Whitney $U$ tests, and two-way analysis of variance (Siegel, 1956; Sokal and Roblf, 1979) were used to test for differences between sexes and among years, using a Vax-1l computer and BMDP statistical software (Dixon, 1983).

Though some mammals depart from a sex ratio of parity at birth (Clutton-Brock et al., 1985; Coulson and Hickling, 1961, Mecb, 1975), the sex ratio of neonatal fallow deer $(n=57)$ was not different from unity (females/males $=0.97)$ Sex ratio varicd annually from 0.71 in $1982(n=12)$ to 1.80 in $1984(n=14)$, but did not differ significantly from unity in any year.

Despite the nearly equal sex ratio obtained, differences were found in relation to the birth dates of fawns. We noted a tendency for males to be born earlier than females, with a significant differenee in 1983 (Table 1). Similar differences in birth timing between male and female progeny have been fonnd for seals (Halichoerus grypus and Leptonychotes weddelli; Coulson and Hickling, 1961; Stirling, 1971) and for red deer (Cervus elaphus; Clutton-Brock et al., 1982). As indicated by the lower variance in hirth dates (Table 1), males were born within a shorter period than females. Birthing season lasted $8,6,5$, and 6 days for males and $12,14,17$, and 9 days for females in 1982, 1983, 1984 and 1985, respectively.

Clutton-Brock el al (1982) found that although males tend to be born before female offspring in red deer, the gestation period is longer for inales, indicating they are conceived earlier in the season. We have no data on dates of conception or the duration of the gestation period for fallow deer.

Male offspring were significantly heavier than females (Table 2). Differences in birth weight between the sexes have been observed in red deer (Clutton-Brock et al., 1981, 1982; Guinness et al., 1978). Furthermore, our results indicated that males were signiticantly larger than females at birth for five of six linear measurements (Table 2). These differences in the size of male and female offspring suggested that maternal investment before birth is larger in individuai sons than in individnal daughters.

A signifieant increase in the weight of offspring and in hindfoot length was detected during the 4-year study (Table 2) This increase was greatest between 1983 and 1984 The drought on the Doñana Reserve in 1980 and 1981 had an important effect on the size of the population and on the physical condition of 


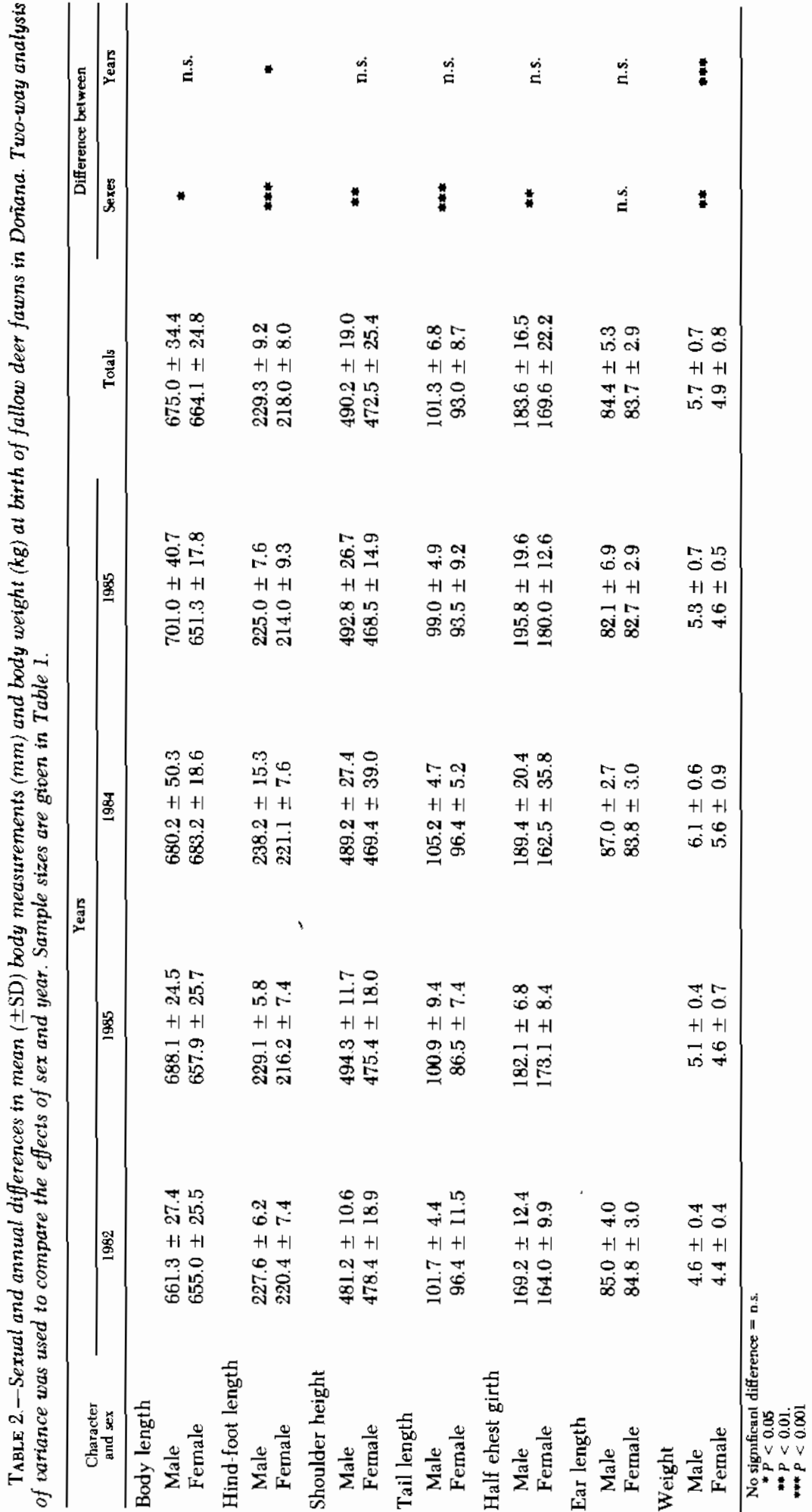


individuals. Clutton-Brock et al. (1982) found a positive eorrelation between weather eonditions and the weight of offspring at birth for red deer; a similar correlation seems to exist for the fallow deer in Donana. Though the average rainfall in Doñana in 1982 was higher than 1980-1981, its distribution was irregular. For this reason, eomplete physieal recovery of individuals was not possible after the 2 years of drought, all of whieh was reflected in an atypical rutting season in autumn of 1982 (Braza et al, 1986). An increase in the size of offspring did not result until the spring of 1984. Although weight and size of fawns varied across years, males were significantly heavier and larger than females in all years.

In conclusion, although the sex ratio did not differ significantly from parity, our results on biometry and birth dates appear to support the hypothesis of higher parental investment in male offspring during gestation.

We thank Ivan Varela for his help and Annie Simon, Rita Braza, Clair Noëlle, and Pierre Eric for their assistance during the field work. Carolina Carazo and Fernando Campos also made an important contribution in the final stage of preparation of the manuscript. Dr. F. Alvarez, Enrique Collado, and Dr. T. CluttonBrock also read the manuscript critically.

\section{Literature Cited}

Braza, F. 1975. Censo del gamo (Dama dama) en Doñana. Naturalia Hispánica, 3:1-27.

Braza, F, J. E. Garcia, and F. Alvarez. 1986. Rutting behaviour of fallow decr. Acta Theriol., 31:467-478.

Clutton-Brock, T. H., and S. D. Albon. 1979. The roaring of red deer and the evolution of honest advertisement. Behaviour, 69·146-169.

Clutton-Brock, T. H., S. D. Albon, and F. E. Guinness. 1981. Parental investment in malc and female offspring in polygynous mammals. Nature, 289:487-489.

Clutton-Bhock, T. H., F. E. Guinness, and S. D. Albon. 1982. Red deer. Behaviour and ecology of two sexes. Edinburgh Univ. Prcss, Edinburgh, 378 pp.

Clutton-Brock, T. H., M. Major, and F. E. Guinness. 1985. Populatiou regulation in male and female red deer. J. Anim. Ecol., 54:831-846.

Coulson, J. C., and G. Hickling. 1961. Variation in the secondary sex-ratio of the grey seal Halichoerus grypus (Fab.) during the breeding season. Nature, 190281 .

Ditrus, W. P. J. 1979. The evolution of behaviour regulating density and age-specific sex ratios in a primate population. Behaviour, 69:265-301.

Dixon, W. J. 1983. BMDP statistieal software. Univ. California Press, Berkeley, 733 pp.

Guinness, F E, S. D. Albon, AND T. H. Clutron-Brock, 1978. Faetors affecting reproduction in red deer (Cervus elaphus L.) J. Reprod. Fert., 54:325-334

Haugen, A. O., and D. W. Speak. 1958. Determining age of young fawn white-tailed deer. J. Wildl. Mgmt., 22:319-321.
Le Boeuf, B. J., and K. T. Briggs. 1977. The cost of living in a seal harem. Mammalia, 41:167-195.

Maynard-Smith, J. 1980. A new theory of sexual investment Behav. Ecol. Soeiobiol., 7:247-251.

MECH, L. D. 1975. Disproportionate sex ratios of wolf pups. J. Wildl. Mgmt., 39:737-740.

Reiter, J., N. L. Stinson, and B. J. Le Boeuf. 1978. Northern elephant seal development: the transition from weaning to nutritional independenee. Behav. Ecol. Sociobiol., 3:337-367.

Robbins, C. T., AND A. N. Moen. 1975. Milk consumption and wcight gain of white-tailed deer. J. Wildl. Mgmt., 39:355-360.

Shont, C. 1970. Morphological development and aging of male and white-tailed deer fetuses. J. Wildl. Mgmt., 34:383-388.

SIEgeL, S. 1956. Nonparametric statistics for the behavioral sciences. McGraw-Hill Book Co., New York, $312 \mathrm{pp}$.

Sokal, R R., AND P. J. RohlF. 1979. Biometria. Prineipios y métodos cstadísticos en la investigación biológica. H. Blumc Ediciones, Madrid, 832 pp.

STIRLING, I. 1971. Variation in sex ratio of newborn weddell seals during the pupping season. J. Mamm., 52:842-844.

Triver5, R. L. 1972. Parental investment and sexual selection. Pp. 52-97, in Readings in sociobiology (T. H. Clutton-Brock and P. H. Harvey, eds.). W.H. Freeman and Co., San Francisco, 393 pp.

1985. Social evolution. Benjamin-Cummings Co., Menlo Park, California, 462 pp.

Trivers, R. L., AND D. E WILlard. 1973. Natural selection of parental ability to vary the sex ratio of offspring. Scienee, 179:90--92. 